Diabetes and Protein Glycosylation 
Margo Panush Cohen

\section{Diabetes and \\ Protein Glycosylation}

Measurement and Biologic Relevance

With a Foreword by Harold Rifkin

With 32 Figures

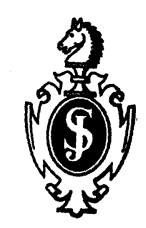

Springer-Verlag

New York Berlin Heidelberg Tokyo 


\author{
Margo Panush Cohen \\ Professor of Medicine and Chair \\ Division of Endocrinology \\ and Metabolism \\ University of Medicine \\ and Dentistry of New Jersey \\ Newark, New Jersey 07103 \\ U.S.A.
}

Library of Congress Cataloging in Publication Data

Cohen, Margo P.

Diabetes and protein glycosylation.

Bibliography: $p$.

Includes index.

1. Diabetes. 2. Glycoproteins. 3. Glycosylated

hemoglobin. I. Title. [DNLM: 1. Diabetes Mellitus-

metabolism. 2. Glycoproteins-biosynthesis.

WK 810 C678d]

$\begin{array}{llll}\text { RC660.C473 } 1986 \quad 616.4^{\prime} 62 & 86-3949\end{array}$

(ㄷ 1986 by Springer-Verlag New York Inc.

All rights reserved. No part of this book may be translated or reproduced in any form without written permission from Springer-Verlag, 175 Fifth Avenue, New York, New York 10010, U.S.A.

The use of general descriptive names, trade names, trademarks, etc. in this publication, even if the former are not especially identified, is not to be taken as a sign that such names, as understood by the Trade Marks and Merchandise Marks Act, may accordingly be used freely by anyone.

While the advice and information in this book are believed to be true and accurate at the date of going to press, neither the authors nor the editors nor the publisher can accept any legal responsibility for any errors or omissions that may be made. The publisher makes no warranty, express or implied, with respect to the material contained herein.

Typeset by Ampersand Publisher Services Inc., Rutland, Vermont.

Printed and bound by R.R. Donnelley \& Sons, Harrisonburg, Virginia.

Printed in the United States of America.

987654321

ISBN-13: 978-1-4612-9366-8

e-ISBN-13: 978-1-4612-4938-2

DOI: $10 / 1007-978-1-4612-4938-2$ 
To Louis and Tillie Panush

and to Perry, Michael, Daniel, and Jonathan Cohen 


\section{Foreword}

In the years since the initial discovery that blood from diabetic patients contains increased amounts of a posttranslationally glucosylated form of hemoglobin (hemoglobin $A_{1 c}$ ), an impressive number of studies have clarified and expanded the use of glycohemoglobin levels to assess disease status. Many other structural proteins have been shown to undergo similar changes, including proteins from tissues most commonly affected in diabetes (e.g., lens, aorta, peripheral nerve, basement membrane). Thus, the nonenzymatic glycosylation of hemoglobin emerges as an invaluable model for the pathogenesis of certain chronic diabetes complications.

In addition to reviewing a wealth of investigative possibilities in the area of these chronic complications-including eye, kidney, nerve, and vascular disease-Dr. Cohen indicates how enhanced nonenzymatic glycosylation in uncontrolled diabetes underscores the pressing need for maintenance of long-term euglycemia.

Dr. Cohen is an endocrinologist and diabetes specialist whose research activities have largely focused on the chemistry and metabolism of the basement membrane in diabetes. This superb monograph on nonenzymatic glycosylation clearly shows the major trends of her past and present research and clinical activities.

This book is beautifully written and a pleasure to read. It provides great insight into the mechanisms of the pathogenesis of the compli- 
cations of diabetes and should be of immense value not only to basic and clinical investigators, but also to internists, diabetologists, and endocrinologists in clinical practice.

\section{HAROLD RIFKIN}

Clinical Professor of Medicine

Albert Einstein College of Medicine

Professor of Clinical Medicine

New York University School of Medicine

Principal Consultant

Diabetes Research and Training Center

Albert Einstein College of Medicine

Montefiore Medical Center

New York, New York 


\section{Preface}

Nonenzymatic glycosylation of proteins, long known to food chemists as the "browning" reaction, has become the subject of a surge of interest that has made its biologic relevance-particularly in diabetes-increasingly clear in recent years. Hyperglycemia promotes the enhanced nonenzymatic glycosylation of both circulating and tissue proteins, thereby not only allowing the assessment of diabetes control through determination of glycohemoglobin and glycoalbumin levels, but also providing insight into the pathogenetic mechanisms associated with the chronic complications of diabetes, as well as with the aging process.

Diabetes and Protein Glycosylation: Measurement and Biologic Relevance was written with the conviction that the crucial role of glucose in the pathogenesis of diabetic complications can no longer be ignored. A comprehensive discussion of the chemistry, methods for measurement, clinical use and abuse, and pathophysiologic consequences of nonenzymatic protein glycosylation should be of value to all physicians concerned with the diagnosis and management of diabetes and to clinical and basic science investigators interested in the biochemical basis of the disease's sequelae.

New York, New York

M.P. COHEN

February 1986 


\section{Contents}

1. Introduction $\ldots \ldots \ldots \ldots \ldots \ldots \ldots \ldots \ldots \ldots \ldots \ldots \ldots \ldots, 1$

References.............................. 3

2. Chemistry $\ldots \ldots \ldots \ldots \ldots \ldots \ldots \ldots \ldots \ldots \ldots \ldots \ldots \ldots \ldots \ldots, 5$

Condensation of Glucose With Proteins ............ 5

Other Monosaccharides ...................... 9

Modifying Factors ............................ 10

Maillard Browning $\ldots \ldots \ldots \ldots \ldots \ldots \ldots \ldots \ldots \ldots \ldots, 12$

References.............................. 14

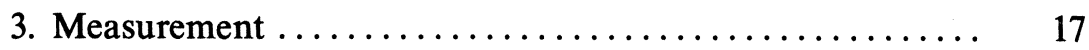

Circulating Proteins $\ldots \ldots \ldots \ldots \ldots \ldots \ldots \ldots \ldots \ldots \ldots \ldots \ldots$

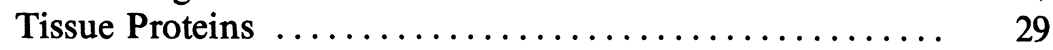

References............................. 35

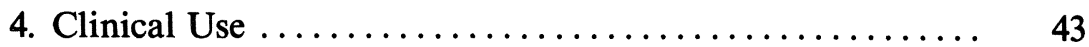

Monitoring Glycemic Control ................. 43

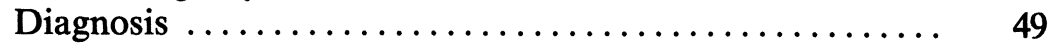

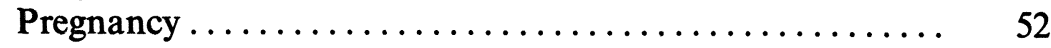

Complications of Diabetes .................... 55

References............................ $\quad{ }_{58}$ 
5. Pathophysiologic Significance $\ldots \ldots \ldots \ldots \ldots \ldots \ldots \ldots, \quad 67$

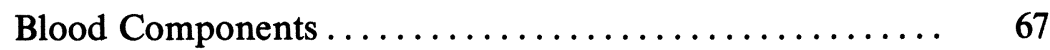

Enzymes and Hormones ..................... 77

Tissue and Structural Proteins ................... 79

Advanced Glycosylation End Products .............. 94

References............................. 101

Bibliography........................... 113



